\title{
Vocabulary Self-Collection Strategy: Is It Effective to Improve Vocabulary Mastery Achievement on Senior High School Students?
}

\author{
Rizal Arisman ${ }^{l}$ \\ Uniiversitas Dayanu Ikhsanuddin ${ }^{l}$ \\ rizalarisman@unidayan.ac.id
}

\begin{abstract}
The objective of this research was to find out whether there was a significant difference in vocabulary mastery between students who were taught using vocabulary self-collection strategy and those who were taught using a conventional method. This research used a quantitative approach with the experimental method of quasi-experimental design. There were 60 students involved as a sample of this research selected using the purposive cluster sampling technique. The instrument used was a test including pretest and posttest. Data were analyzed using Mann Whitney $U$ test. The result indicated that the score of Asymp Sig. (2-tailed) was 0.001 which was fewer than $\alpha$ (0.05). It meant there was a significant difference in vocabulary mastery between students who were taught using vocabulary self-collection strategy and those who were taught using the conventional method. Furthermore, based on the result of the N-Gain test, it was found that the vocabulary self-collection strategy was more effective than the conventional method.
\end{abstract}

\begin{abstract}
ABSTRAK
Tujuan penelitian ini adalah untuk mengetahui apakah ada perbedaan yang signifikan pada penguasaan kosakata antara siswa yang diajar menggunakan strategi vocabulary self-collection dan yang diajar menggunakan metode konvensional. Pendekatan yang digunakan dalam penelitian ini adalah kuantitatif dengan metode eksperimental desain kuasi eksperimental. Ada 60 siswa yang terlibat dalam penelitian ini sebagai sampel yang dipilih menggunakan teknik sampling kelompok purposif. Instrumen yang digunakan adalah tes meliputi tes awal dan tes akhir. Data dianalisis menggunakan uji Mann Whitney $U$. Hasilnya menunjukkan bahwa nilai Asymp Sig. (2-tailed) sebesar 0,001 yang lebih kecil dari $\alpha$ $(0,05)$. Artinya ada perbedaan yang signifikan pada penguasaan kosakata antara siswa yang diajar menggunakan vocabulary self-collection strategy dan yang diajar menggunakan metode konvensional. Lebih jauh lagi berdasarkan nilai uji $\mathrm{N}$-Gain, diketahui bahwa vocabulary self-collection strategy lebih efektif daripada metode konvensional.
\end{abstract}

\author{
KEYWORDS \\ Vocabulary Self-Collection \\ Strategy; Vocabulary \\ Mastery Achievement
}

\section{KATA KUNCI}

Strategi Vocabulary SelfCollection; Kemampuan Penguasaan Kosakata 


\section{INTRODUCTION}

Mastering vocabulary is important in getting know any language. This is due to the fact vocabulary is built into all elements of the language, to be specific reading, writing, speaking and listening. While not having sufficient vocabulary, it must be not possible to gather proper abilities in any language skill. (Carranza et al., 2015) argues that being not able to communicate meaningfully is irrespective of how kids can examine grammar, no matter of how the sounds of an L2 are learned, as long as there are not any words with which to carry a plus huge variety of meanings. Since English becomes the foreign language in Indonesia, it includes in school curriculum from elementary to high school. Saengpakdeejit (2014) states that despite frequent usage of the English language both in and out of the classroom, students continue to face difficulties in their learning, and they usually see unfamiliar terms as the first obstacle to overcome. Asgari \& Mustapha (2011) are sure that can be due to the fact that vocabulary has been acknowledged as being critical to language usage, and that learners with inadequate vocabulary knowledge have had problems in second language acquisition

Thinking about the significance of mastering vocabulary, it ought to learn using the suitable in strategy that students' vocabulary mastery can be stepped forward, mainly at the senior school level in Baubau, Southeast Sulawesi. It is supported by Kafipour and Naveh (2011) which argue that The use of learning methods is very essential in the process of vocabulary acquisition, and it is highly dependent on the efforts of the learners. Learning methods for vocabulary are a subset of language learning strategies that have received a great deal of attention since the late 1970s. When it comes to learning words independently, a vocabulary strategy is a specific instructional instrument and method of going about it directly or explicitly, as well as the independent word learning abilities needed to do so.

As stated by Nation (2001), the languages of reading, listening, speaking and writing have two distinct forms of vocabulary. This vocabulary is receptive, productive, passive and active. Receptive or passive vocabulary refers to words identified and understood by local and overseas speakers, which might be hardly ever used anyway. Productive or active vocabulary is actively spoken or written. The vocabulary of the pupil is commonly broader than that of the speakers, even as the vocabulary of the pupil is pretty massive. The reception vocabulary in most language novices is significantly large than its productive vocabulary, however, Nation \& Waring (1997) have proven the quantity to which this relationship is not ordinary or predictable. Likewise, Corson (1997) differentiates productivity from receptivity within the following way. He calls a stimulated vocabulary productive vocabulary. It consists of all the phrases that pupils need in regular communication. A receptive vocabulary consists of efficient speech and the uninspired vocabulary of learners. Unsaid vocabulary may be separated into two forms: (1) words which might be most effective part understood and little acknowledged for active use, and (2) terms that are not needed in regular communication. Furthermore, Hoffman (2015) shows that there are two forms of vocabulary. It is the basic vocabulary and the peripheral language. The key word is the vocabulary containing the words which can be spoken every day. The outermost vocabulary is made up from infinite words which might be not often used.

Gaining knowledge of vocabulary is not just about its form and significance. Ferris \& Hedgcock (2009) advice that word learning consists of layers of meaning, some of syntactic 
Rizal Arisman ${ }^{1}$

J-SHMIC : Journal of English for Academic

Vol 8, No 2, August 2021

guidelines and boundaries (i.e. the grammar of the word), in addition to socially constructed patterns for the right use of the language (words use patterns, which mean pragmatic and sociolinguistic conventions). Consequently, unique attention is needed within the study of vocabulary. Watts in Johnson (2008) examines sure elements of making sure accurate gaining knowledge of vocabulary: (1) repeated exposures which imply that pupils have to come across new words in numerous conditions over time. Seek to introduce new phrases as part of a commonplace tale, theme or subject within the curriculum; (2) significant contexts that are words utilized in vocabulary mastering have to associated as plenty as feasible to the life or experiences of the pupils; (3) Previous expertise, that is, within the context of acknowledged words and ideas, new words ought to continually be delivered. Ask pupils to listing things they recognize about the subject before introducing a new word; (4) links that illustrate or join the connection among new words and well-known words or concepts; (5) the contextual clues and dictionaries that pupils use to discover the lacking or infamous word in the context of a sentence or paragraph; and (6) the manner pupils look up words within the dictionary should be combined with the way they study them, pronounce them and use them; that is, whilst they come across new phrases to see them (as part of a sentence), speak them and use them inside the written or oral context. It has to additionally be mixed with teachers. Richards \& Renandya (2002) noted in their powerful vocabulary teaching that expertise of the vocabulary mastered by pupils so as to understand an English passage have to encompass understanding of the synonym, antonymic understanding, derivative expertise, knowledge of the connector / connection and the knowledge of a way to outline words in context.

Thinking about the importance of vocabulary, then it needs to gain knowledge of with the ideal method for learners to collect new vocabulary thru the mastering method within the classroom. The issues seem at the vocabulary of the pupils of SMA Negeri 4 Baubau, Southeast Sulawesi. English teachers introduce English vocabulary using translation and ask pupils to memorize it. Translation ought to be prevented because it has numerous risks such that pupils may have verbalism and no longer all words may be translated. For that reason, many students lose interest and become bored in studying vocabulary. consequently, students' vocabulary fluency could be very low due to the fact students have issue memorizing the new words which have been taught and that they effortlessly forget about the phrases that have been learned earlier than.

By knowing the problem faced by the students at SMA Negeri 4 Baubau above, the researchers suggest one strategy to overcome it. Researchers use the Self-Vocabulary Collection (VSS) strategy to educate vocabulary to enhance pupils' vocabulary fluency. The VSS turned into evolved with the aid of Ruddell in 2005. It applied inside the classroom of seventh grade, high school and graduate students. Antonacci et al., (2014) state that The VSS's goal is to provide a long-term incentive for pupils to acquire new words by raising their interests in integrating new topic words into their educational vocabulary over time. As students use VSS, they maintain their study approach, locate the ideal words to use, expand their vocabularies, and become word mindful (Martin, 2015). Moreover, Haggard in Putri (2012) indicates that there are three benefits to adopting VSS: making a connection among new words and their meanings, growing pupil interest in new phrases, and growing students' passion for learning and the invention of latest words. Evidently VSS makes the studying method more exciting and fun for the pupil. Students are not going to be bored throughout the interest as they will now not simplest be asked to reply questions related to the textual 
content without any coaching, however may also be asked to examine the text on the way to additionally identify new and important words. In addition, the involvement of teachers in supervising students by activities has a large effect on the capability of students to examine correctly.

From the outline of VSS above, it could be concluded that using VSS can improve students' vocabulary mastery through making the studying more fun, bringing enthusiasm for students at some point of the studying process, and motivating the students to accumulate new words. Except, researches display the achievement of the usage of VSS to enhance students' vocabulary mastery. The students increased their activeness within the class and have been courageous to ask and answer some questions (Rahman et al., 2019) and it helped the students developing their vocabulary (Khodary, 2017). Therefore, the VSS is applied by the researcher on grade eleven students at SMA Negeri 4 Baubau by expecting that strategy will encounter students' vocabulary learning problems which leads to the improvement of their vocabulary mastery achievement.

By looking at the explanation above, this research comes with the problem as follows: Is there any significant difference on vocabulary mastery achievement between who are taught using VSS and those who are not on grade eleven students at SMA Negeri 4 Baubau? Therefore, this research aims to find out whether the application of VSS is better to improve the students' vocabulary mastery achievement than a conventional method at SMA Negeri 4 Baubau.

\section{METHOD}

A quantitative approach of quasi experimental design was used for this research. This intended that these studies used groups of students, where in one group changed into dealt with as a control group and some other group turned into handled as an experimental group. The students concerned in this studies were eleventh grade students from SMA Negeri 4 Baubau, with a total number were 184 students. The samples have been class MIA-4 as an experimental class and class MIA-7 as a control class with a total number were 60 students. They were selected as samples using the purposive cluster sampling technique. It meant each group of students who had low vocabulary learning achievement had the opportunity to be selected as the sample of this research.

To collect the data, this research needed an instrument. The instrument used was a vocabulary test. It was linked to the receptive or productive ability of a language overall (Nurgiyantoro, 2017). The test was divided into pretest and posttest. They are made in form of a multiple-choice item with had five options for each item. In administering the tests, the researcher explained first to the students and invited the students to ask whether there was something they did not understand about the instruction. The tests were administering for 60 minutes. Before administering the posttest or after administering the pretest, the treatment was done. It was a process of teaching and learning in both experimental and control classes using VSS for six meetings. The data accumulated throughout the tests is analyzed using descriptive statistics to decide students' vocabulary fluency earlier than and after treatment and inferential statistics to determine if there was a huge distinction in vocabulary fluency among the students. students who have learned to apply self-collecting vocabulary approach 
and those which have been taught using the conventional approach. Further, the previous analysis which includes a homogeneity and normality take a look at turned into carried out to outline whether or not the speculation test used parametric or nonparametric exams. The normality check used the Kolmogorov-Smirnov test considering a total number of students were 60. Whilst the homogeneity test used the Levene test for the variance of equality.

The students' answers were calculated to find out the mean score. Its score is used to determine the level of their vocabulary mastery achievement by using the following formula from Rahimi (2016) as follows:

Table 1: Level of students' vocabulary mastery achievement.

\begin{tabular}{|c|c|c|}
\hline No & Scoring Range & Category \\
\hline 1 & $91-100$ & Excellent \\
\hline 2 & $81-90$ & Very Good \\
\hline 3 & $71-80$ & Good \\
\hline 4 & $61-70$ & Fair \\
\hline 5 & $51-60$ & Poor \\
\hline 6 & $0-50$ & Very Poor \\
\hline
\end{tabular}

\section{FINDING AND DISCUSSION}

This research is conducted on grade-eleven students at SMA Negeri 4 Baubau. It takes two classes as the sample. Each class consists of 30 students. So, the total number of samples is 60 students. Since this research uses a test as the research instrument, the researcher administers the pretest first, then does the treatment, and finally administers the posttest. 30 items of the multiple-choice test must be answered by the students to find out their achievement before and after the implementation of VSS in mastering vocabulary. The results of each test both in experimental and control class are explained below.

To know the students' initial vocabulary mastery, the pretest is administered. The data obtained from the pretest are then analysed using descriptive statistics through SPSS. The result of the analysis obtains the mean score that is 62.83 , the standard deviation is 7.54 , the minimum score is 45.00, and the maximum score is 75.00. From the dispersion of the students' scores, their level of vocabulary mastery achievement can be seen in the following table.

Table 2: Vocabulary mastery achievement in pretest at experimental class.

\begin{tabular}{|c|c|c|c|c|}
\hline No & Scoring Range & Category & Frequency & Percentage \\
\hline 1 & $91-100$ & Excellent & 0 & 0.00 \\
\hline 2 & $81-90$ & Very Good & 0 & 0.00 \\
\hline 3 & $71-80$ & Good & 3 & 13.33 \\
\hline 4 & $61-70$ & Fair & 5 & 36.67 \\
\hline 5 & $51-60$ & Poor & 19 & 40.00 \\
\hline 6 & $0-50$ & Very Poor & 3 & 10.00 \\
\hline \multicolumn{3}{|c|}{ Total } & 30 & 100 \\
\hline
\end{tabular}


Rizal Arisman ${ }^{l}$

J-SHMIC : Journal of English for Academic

Vol 8, No 2, August 2021

From the data of score above, it can be known that there is not any student achieving excellent category. While there are 3 students or $10 \%$ achieves very poor category. It means there are just 3 students or $10 \%$ of total students who have the very poor achievement of mastering vocabulary. Besides by looking at the table, it can be known that there are 21 students or $50 \%$ of total students get under average achievement. Based on the data presented above, it is concluded that the students' achievement of mastering vocabulary before being taught using VSS is in the poor category. It is because most students' scores in the pretest are in that category.

A treatment that uses VSS is then applied to the experimental class for 6 meetings. As it is finished, a posttest is administered to find out the students' vocabulary mastery achievement. Also, it is used to find out whether the strategy is effective to enhance the level of vocabulary mastery achievement. The result of descriptive testing obtains the mean score that is 79.67 , the standard deviation is 7.98 , the minimum score is 70.00 , and the maximum score is 95.00 . The table below presents the students' score dispersion based on the category of vocabulary mastery achievement.

Table 3: Vocabulary mastery achievement in posttest at experimental class.

\begin{tabular}{|c|c|c|c|c|}
\hline No & Scoring Range & Category & Frequency & Percentage \\
\hline 1 & $91-100$ & Excellent & 3 & 10.00 \\
\hline 2 & $81-90$ & Very Good & 7 & 23.33 \\
\hline 3 & $71-80$ & Good & 13 & 43.34 \\
\hline 4 & $61-70$ & Fair & 7 & 23.33 \\
\hline 5 & $51-60$ & Poor & 0 & 0.00 \\
\hline 6 & $0-50$ & Very Poor & 0 & 0.00 \\
\hline \multicolumn{4}{|r|}{ Total }
\end{tabular}

The students' scores in the posttest as displayed in the table above reveal that there is not anymore student who achieve very poor category. While excellent and very good category are achieved by 10 students or $33.33 \%$ of the total students which there are not any students who achieve those levels in the pretest. Besides, the result of the posttest indicates no more students achieve very poor and poor mastery achievement. So that by looking at the score, it can be said that there is an improvement of vocabulary mastery achievement after being taught using VSS. Of all the categories of achievement, it can be concluded that the students' vocabulary mastery achievement is in good category since it is the category achieved by most students. From the result, it is known that the VSS improves the students' vocabulary mastery achievement.

Not only in the experimental class but also control class the pretest is administered. The result of descriptive testing obtains the mean score that is 58.33, the standard deviation is $\mathbf{1 7 . 3 9}$, the minimum score is 35.00 , and the maximum score is 90.00 . The scores are then consulted to the level of vocabulary mastery achievement and the following table presents the result.

Table 4: Vocabulary mastery achievement in pretest at control class.

\begin{tabular}{|c|c|c|c|c|}
\hline No & Scoring Range & Category & Frequency & Percentage \\
\hline 1 & $91-100$ & Excellent & 0 & 0.00 \\
\hline 2 & $81-90$ & Very Good & 4 & 13.33 \\
\hline 3 & $71-80$ & Good & 3 & 10.00 \\
\hline 4 & $61-70$ & Fair & 4 & 13.33 \\
\hline
\end{tabular}


Rizal Arisman ${ }^{l}$

J-SHMIC : Journal of English for Academic

Vol 8, No 2, August 2021

\begin{tabular}{|c|c|c|c|c|}
\hline 5 & $51-60$ & Poor & 6 & 20.00 \\
\hline 6 & $0-50$ & Very Poor & 13 & 43.34 \\
\hline \multicolumn{2}{|c|}{ Total } & 30 & 100 \\
\hline
\end{tabular}

The table above reveals that there is not any student who has excellent achievement in vocabulary mastery. While the number of students in under average level is more than in over average, that is 18 students or $60 \%$ of total students. Besides, among all categories of vocabulary mastery achievement, the very poor category is achieved by most students. Therefore, it can be concluded that the students have very poor achievement in vocabulary mastery. Then in the control class, a treatment using the conventional method is applied for six meetings. A post-test is administered as the treatment is done. The students' answers are analyzed using descriptive statistics and it obtains the data, such as the mean score is 69.83 , the standard deviation is 13.55 , the minimum score is 50.00 , and the maximum score is 95.00. The result is displayed in the table below.

Table 5: Vocabulary mastery achievement in posttest at control class.

\begin{tabular}{|c|c|c|c|c|}
\hline No & Scoring Range & Category & Frequency & Percentage \\
\hline 1 & $91-100$ & Excellent & 3 & 10.00 \\
\hline 2 & $81-90$ & Very Good & 4 & 16.67 \\
\hline 3 & $71-80$ & Good & 2 & 16.67 \\
\hline 4 & $61-70$ & Fair & 12 & 26.67 \\
\hline 5 & $51-60$ & Poor & 7 & 23.33 \\
\hline 6 & $0-50$ & Very Poor & 2 & 6.67 \\
\hline
\end{tabular}

The score obtained by the students in the posttest indicates that there is a decrease in the number for the very poor category, but the poor category is increased. Furthermore, there have been 3 students or $10 \%$ of total students achieve excellent category. On the other hand, there is an increase in students' achievement in the excellent category in which there is not any student achieve the category in pretest but there 3 students have excellent achievement in the posttest. The data reveals that there also an improvement of vocabulary mastery achievement from pretest to posttest. Overall, the students' vocabulary mastery achievement in the posttest is in the fair category, since it is the category of achievement that most students achieve.

The prerequisite analysis is used before the hypothesis testing is done. Kinds of the analyses are homogeneity and normality test. The following table presents the result of the homogeneity test.

Table 6: Levene's test of homogeneity.

\begin{tabular}{|c|c|c|c|}
\hline Levene's Statistic & df1 & df2 & sig. \\
\hline 5.593 & 1 & 58 & 0.021 \\
\hline
\end{tabular}

The result of the homogeneity test uses Levene's test as presented in the table above indicates that the significance value is 0.021 which is lower than 0.05 . Therefore, it is concluded that the data are not normally distributed. The normality test using the Kolmogorov-Smirnov test is the next step to do. The following table shows the result. 
Table 7. Normality Test of Kolmogorov-Smirnov.

\begin{tabular}{|c|c|c|c|}
\hline \multirow{2}{*}{ Group } & \multicolumn{3}{|c|}{ Kolmogorov-Smirnov } \\
\cline { 2 - 4 } & Statistic & $\mathrm{df}$ & Sig. \\
\hline Experimental Class & 0.154 & 30 & 0.067 \\
\hline Control Class & 0.195 & 30 & 0.005 \\
\hline
\end{tabular}

The data in the table above show that the significance value in the experimental class is 0.0067 and it is 0.005 in the control class for the number of students is 30 in each class. Furthermore, the significance value is the experimental class is higher than 0.005 , but it is not the control class. It means the data in the experimental class is normally distributed, but in the control class, it is not normal. Since not both groups have a normal distribution of data and the data are also not homogenous, the hypothesis testing is used the Mann-Whitney $U$ test from nonparametric statistics. The result of the test is as follows:

Table 8. Result of Mann-Whitney U Test

\begin{tabular}{|c|c|}
\hline & Vocabulary Achievement \\
\hline Mann-Whitney U & 223.500 \\
\hline Wilcoxon-W & 688.500 \\
\hline Z & -3.380 \\
\hline Asymp Sig. (2-tailed) & 0.001 \\
\hline
\end{tabular}

The above table shows the score obtained on the Mann-Whitney U test. The score is used to decide whether or not the hypothesis of this study is accepted or rejected. There are decided hypotheses; $\mathrm{Ha}$ is there a significant difference in vocabulary mastery between students who study the use of the self-collecting vocabulary approach and those who learn using the conventional approach and Ho there's no substantial difference in vocabulary fluency between students who learn using the self-accumulating vocabulary strategy and people who are taught using the conventional method. If Asymp Sig. (bilateral) is much less than 0.05, the Ha is accepted, however if Asymp Sig. (2 tails) is extra than 0.05, Ho is accepted. it may be visible that the Asymp Sig. score (2-tailed) is 0.001. Consequently, Ha is accepted and Ho is rejected. Further, the N-gain check is implemented to discover which method is most effective. The end result exhibits that the mean score of the experimental magnificence is $47.75 \%$ and $25.11 \%$ inside the control class. Consequently, the vocabulary self-collection approach is more effective than the conventional approach.

The outcomes which have been offered in the results describe the pre and post test result in each the experimental class and the control class. The experimental class is taught using a vocabulary self-collection approach, whilst the control class is taught using the conventional approach. The data exhibits that there is a development in the performance of the students in the mastery of vocabulary in the experimental class that can be seen within the development of the average rating of as much as 13.96 points. For assessment, in the control class, the mean post-test score is 11.50 points better than the pre-test. These outcomes also are supported by the end result of the $\mathrm{N}$-gain test to discover the effectiveness of every approach. The experimental class is assessed as moderate, at the same time as the control class is assessed as poor. 
Rizal Arisman ${ }^{l}$

J-SHMIC : Journal of English for Academic

Vol 8, No 2, August 2021

Even though this research is just focused on the students' vocabulary mastery achievement through VSS in which the purpose of VSS is to enable the long-term acquisition of vocabulary (Stoddard, 2006), but some researches also prove that VSS is effective on students' vocabulary learning motivation and behavior (Simbolon et al., 2020), to motivate students to learn vocabulary since they do not feel bored and enjoy the class (Mandasari, 2013) and actively join the learning (Meiningsih, 2015). The results support the statement from Tompkins (2010) that VSS is a means of intrinsically motivating learners to build academic and specialized vocabulary.

\section{CONCLUSION}

Primarily based on the end result of the data analysis as provided formerly within the descriptive analysis, supported through the hypothesis test and the effectiveness test, this research concludes that there's a significant difference in the achievement of vocabulary proficiency among students at those that are taught using self-taught vocabulary. Collection strategy and those who are taught through the conventional approach. it may be seen inside the average score of the posttest in which inside the experimental class it is 79.67 and it is categorized as good. It means that students gain an awesome command of vocabulary after being taught using the vocabulary self-collection strategy.

For contrast, the mean posttest score in the control class is 69.83 and is classified as fair. It reveals that the students have an appropriate achievement in vocabulary mastery after being taught using the conventional method. Moreover, the results of the efficacy tests conclude that the vocabulary self-collection approach is greater effective than the conventional approach. From the end result of the N-gain test, it may be regarded that the mean score within the experimental class is $47.75 \%$ and it is $25.11 \%$ within the control class. Observing the result of each groups, this research suggests to use the vocabulary selfcollection strategy in teaching vocabulary, since it is better to improve students' vocabulary mastery achievement than the conventional method.

\section{REFERENCES}

Antonacci, P. A., O’Callaghan, C. M., \& Berkowitz, E. (2014). Developing content area literacy: 40 strategies for middle and secondary classrooms. Sage Publications.

Asgari, A., \& Ghazali bin Mustapha. (2011). Announcement of retraction. International Education Studies, 4(2), 7. https://doi.org/10.5539/ies.v5n4p150

Carranza, E. F., Manga, A. A., Dio, R. V, Jamora, M. J. A., \& Romero, F. S. (2015). Vocabulary learning and strategies used by teacher education students. Asia Pacific Journal of Multidisciplinary Research, 3(2), 49-55.

Corson, D. (1997). The learning and use of academic English words. Language Learning, 47(4), 671-718. 
Rizal Arisman ${ }^{l}$

J-SHMIC : Journal of English for Academic

Vol 8, No 2, August 2021

Dana R Ferris, \& Hedgcock, J. S. (2009). Teaching readers of English: students, texts, and contexts. Routledge.

Hofmann, T. R. (2015). Realms of meaning: An introduction to semantics. Routledge.

Johnson, A. P. (2008). Teaching reading and writing: A guidebook for tutoring and remediating students. R\&L Education.

Kafipour, R., \& Naveh, M. H. (2011). Vocabulary learning strategies and their contribution to reading comprehension of EFL undergraduate students in Kerman Province. European Journal of Social Sciences, 23(4), 626-647.

Khodary, M. M. (2017). Using the Vocabulary Self-Collection Strategy Plus to Develop University EFL Students' Vocabulary Learning. English Language Teaching, 10(8), 135. https://doi.org/10.5539/elt.v10n8p135

Mandasari, Y. (2013). Enriching Students' vocabulary by combining vocabulary selfcollection strategy and possible sentence strategy in teaching reading at junior high school. Jurnal Pendidikan Bahasa Inggris, 2(2).

Martin, A. (2015). Essential Strategies for Teaching Vocabulary: A Brief Overview Of Vocabulary Development.

Meiningsih, F. A. (2015). The Effectiveness of Vocabulary Self-Collection and Interactive Cloze Strategy to Improve Students' Vocabulary Mastery A Quasi Experimental Study of the Eighth Grade Students of SMP Negeri 3 Ungaran in the Academic Year of 2014/2015. Universitas Negeri Semarang.

Nation, I. S. P. (2001). Learning Vocabulary in Another Language. Ernst Klett Sprachen.

Nation, P., \& Waring, R. (1997). Vocabulary size, text coverage and word lists. Vocabulary: Description, Acquisition and Pedagogy, 14, 6-19.

Nurgiyantoro, B. (2017). Penilaian Pembelajaran Bahasa Berbasis Kompetensi (Kedua). BPFE-Yogyakarta.

Putri, W. E. (2012). The Effect of Using Vocabulary Self-Collection Strategy (VSS) to Reading Achievement of Elementary School Students. Padang: STIKIP PGRI Sumatera Barat.

Rahimi, R. H. (2016). The Use of Information Gap Activity to Improve Speaking Skill. I(1), 76-102.

Rahman, M. F., Rinaldi, R., \& Santoso, I. (2019). The Use of Vocabulary Self-Collection Strategy to Improve Students' Vocabulary Mastery. PROJECT (Professional Journal of English Education), 2(2), 194-200.

Richards, J. C., \& Renandya, W. A. (2002). Methodology in language teaching: An 
Rizal Arisman ${ }^{l}$

J-SHMIC : Journal of English for Academic

Vol 8, No 2, August 2021

anthology of current practice. Cambridge university press.

Saengpakdeejit, R. (2014). Strategies for Dealing with Vocabulary Learning Problems by Thai University Students. Silpakorn University Journal of Social Sciences, Humanities, and Arts, 14(1), 147-167.

Simbolon, P. A., Bangun, F. A. B., Pardede, S. M., Tarigan, J. B., \& Tarigan, S. N. B. (2020). Using Vocabulary Self-Collection Strategy (VSS) to Improve Mastery Student's Vocabulary. Linguistic, English Education and Art (LEEA) Journal, 3(2), 287-295.

Stoddard, T. (2006). Vocabulary Self-Collection Strategy with an example from Ender's Game by Orson Scott Card.

Tompkins, G. E. (2010). Literacy for the 21 st century: A balanced approach Patrick F. Briggs. Boston, MA: Pearson. 